\title{
STUDI EPIDEMOLOGI HIV/AIDS DI KABUPATEN JEMBRANA BALI
}

\author{
Made Nyandra ${ }^{1}$, Ida Bagus Agung Yogeswara ${ }^{2}$ \\ ${ }^{1}$ Program Studi Kesehatan Masyarakat, Universitas Dhyana Pura \\ ${ }^{2}$ Program Studi Ilmu Gizi Universitas Dhyana Pura \\ madenyandra@yahoo.co.id
}

\begin{abstract}
ABSTRAK
Kecepatan pertumbuhan epidemologi HIV/AIDS dapat disebabkan karena melakukan hubungan seksual dengan resiko yang tinggi misalnya dengan bergonta-ganti pasangan tanpa menggunakan kondom, menggunakan jarum suntik yang tidak steril ataupun telah digunakan berulang misalnya yang terjadi pada para pengidap ketergantungan pada obat-obat terlarang, faktor ekonomi, broken home dan homoseksual. Penderita HIV/AIDS memiliki profesi yang beragam dan yang terbesar berprofesi sebagai ibu rumah tangga. Sumber epidemi HIV/AIDS yang tidak jelas dapat menyebabkan kecepatan pertumbuhannya, sehingga perlu dilakukan penelusuran data epidemologi. Penelitian ini menggunakan metode wawancara untuk mengetahui sumber infeksi HIV/AIDS, lama mengetahui status HIV/AIDS, pekerjaan pasangan, dan perasaan responden serta tanggapan keluarga dan masyarakat saat mengetahui bahwa responden terinfeksi HIV/AIDS. Epidemologi HIV/AIDS di Kabupaten Jembrana disebabkan karena hubungan heteroseksual yaitu sebesar $12,5 \%$ dan $80 \%$ masing-masing responden wanita dan pria, homoseksual sebesar $8 \%$ responden pria, tertular oleh pasangan yaitu sebesar $87,5 \%$ dan $12 \%$ masing-masing responden wanita dan pria.
\end{abstract}

Kata kunci : HIV, AIDS, faktor resiko, epidemologi

\section{ABSTRACT}

Growing HIV/AIDS prevalence can be caused by high risk-sexual behaviour, such as partners change without using condoms, the application of re-used or non-sterile needles of drugs-addicted people, economy factor, broken home and homosexuals. HIV/AIDS sufferers have a diverse professions and the largest population with HIV/AIDS are housewives. Unclear source of the HIV/AIDS epidemic can cause the speed of its growth, therefore the epidemiological data is necessary. This study was an observational experiment using the interview method to find out the source of HIV/AIDS infection, the duration of knowledge of HIV/AIDS status, partners job, and the feelings of respondents and family, and community responses when they found out their HIV/AIDS status. Results showed that HIV/AIDS in Jembrana Regency that was caused by heterosexual relationships were $12.5 \%$ and $80 \%$ for female and male respondent respectively. In homosexual respondents, the prevalence of HIV/AIDS was $8 \%$ for male and no HIV/AIDS was found in women. In the partner respondents, the prevalence of HIV/AIDS were $87.5 \%$ and $12 \%$ for female and male respondents respectively.

Keywords: HIV, AIDS, risk factor, epidemology

\section{PENDAHULUAN}

Jumlah penderita HIV di dunia pada tahun 2013 mencapai 35 juta jiwa yang meliputi 16 juta perempuan dan 3,2 juta anak berusia kurang dari 15 tahun. Jumlah infeksi baru HIV pada tahun 2013 sebesar 2,1 juta yang terdiri atas 1,9 juta dewasa dan 240 ribu anak berusia kurang dari 15 tahun (berdasarkan data United Nations Programme on HIVIAIDS dalam Kementrian Kesehatan Republik Indonesia, 2014). Di Indonesia, HIV/AIDS pertama kali ditemukan di provinsi Bali pada tahun 1987 dan hingga kini sudah menyebar di 386 kabupaten/kota di Indonesia. Berdasarkan data statistik kasus HIV/AIDS di Indonesia pada tahun 2014, jumlah kumulatif penderita HIV dari tahun 1987 sampai dengan 2014 sebesar 150.296 orang sedangkan jumlah kumulatif kasus AIDS sebesar 55.799. Prevalensi kasus AIDS di Bali sebesar 109,52 per 100.000 penduduk provinsi Bali, dengan jumlah kumulatif HIV sebesar 9.637 dan kumulatif kasus AIDS sebesar 4.261 (Ditjen PP dan PL Kemenkes RI, 2014).

HIV/AIDS dapat menular melalui hubungan seks bebas (Oppong, 2013), tranfusi darah yang tercemar HIV/AIDS, penggunaan jarum suntik yang telah digunakan oleh orang yang positif mengidap HIV/AIDS, dan ibu hamil yang mengidap HIV/AIDS terhadap janin yang dikandungnya (Kementrian Kesehatan Republik Indonesia, 2014). Kecepatan pertumbuhan epidemologi HIV/AIDS dapat disebabkan karena 
melakukan hubungan seksual dengan resiko yang tinggi misalnya dengan bergonta-ganti pasangan tanpa menggunakan kondom, menggunakan jarum suntik yang tidak steril ataupun telah digunakan berulang misalnya yang terjadi pada para pengidap ketergantungan pada obat-obat terlarang (BradleySpringer, 2015) National AIDS Commision Republic of Indonesia, 2009). Faktor lain yang dapat menjadi pemicu adalah faktor ekonomi dan broken home (Hermanus et al., 2010) serta hubungan homoseksual (Bradley, 2015; Teran et al., 2015)

Penderita HIV/AIDS di Indonesia berasal dari berbagai profesi seperti supir, pegawai negeri sipil, buruh kasar dan penderita HIV/AIDS terbanyak adalah ibu rumah tangga yaitu sebesar 6.539 orang (Ditjen PP dan PL Kemenkes RI, 2014). Hal ini dapat mengindikasikan bahwa penyebaran HIV/AIDS dilakukan oleh suaminya yang sesungguhnya tidak mengetahui bahwa dirinya telah mengidap HIV/AIDS (Hanizar et $k k$ al., 2015). Sumber epidemik dan faktor - faktor resiko HIV/AIDS yang tidak jelas dapat menyebabkan kecepatan pertumbuhannya, sehingga perlu dilakukan penelusuran data epidemologi. Dengan mengetahui epidemi HIV/AIDS dan faktor - faktor resiko maka dapat dilakukan usaha untuk mengurangi prevalensi HIV/AIDS dan usaha pengobatan bagi penderita HIV/AIDS sehingga dapat memperpanjang masa hidup para penderita HIV/AIDS (Streck, 2015).

Penderita HIV/AIDS di wilayah Kabupaten Jembrana, Provinsi Bali berjumlah 556 orang (Tirthayasa, 2015). Hanya sekitar 228 orang yang mau didampingi oleh para aktivis HIV/AIDS Jembrana dan hanya sekitar $10 \%$ penderita HIV/AIDS di Kabupaten Jembrana yang berani mengakui bahwa mereka mengidap penyakit HIV/AIDS, sehingga informasi epidemi HIV/AIDS di Kabupaten Jembrana dan faktor faktor resiko penyebabnya belum diketahui. Untuk mengetahui epidemi HIV/AIDS di Kabupaten Jembrana maka perlu dilakukan penelitian mengenai faktor-faktor resiko terhadap epidemologi HIV/AIDS di Kabupaten Jembrana.

\section{METODE}

Jenis penelitian yang akan digunakan dalam penelitian ini adalah penelitian observasional dengan rancangan penelitian cross sectional dengan pengukuran variabel sebab (heteroseksual dan homoseksual) dan variabel akibat (epidemologi HIV/AIDS). Penelitian ini dilaksanakan di sekretariat aktivis HIV/AIDS "Jalak Bali" Kabupaten Jembrana. Sekretariat aktivis HIV/AIDS "Jalak Bali" Kabupaten Jembrana merupakan tempat berkumpulnya para relawan aktivis dan para penderita HIV/AIDS wilayah Kabupaten Jembrana dalam melakukan pendampingan kepada para penderita HIV/AIDS, sehingga peneliti akan lebih mudah bertemu dengan penderita HIV/AIDS. Penelitian akan dilaksanakan pada bulan November 2015.

Penelitian ini menggunakan 49 orang responden penderita HIV/AIDS yang terdiri dari 24 orang wanita dan 25 orang pria, dengan usia antara 20 sampai 47 tahun. Responden wanita berusia 2025 tahun berjumlah 3 orang; berusia 26-30 tahun berjumlah 4 orang; 31-35 tahun berjumlah 8 orang; berusia 36-40 tahun berjumlah 3 orang; berusia 4145 tahun berjumlah 3 orang; berusia 46-47 tahun berjumlah 3 orang. Sedang untuk responden pria yang berusia 26-30 tahun berjumlah 3 orang; 31-35 tahun berjumlah 8 orang; berusia $36-40$ tahun berjumlah 6 orang; berusia 41-45 tahun berjumlah 2 orang; berusia $46-47$ tahun berjumlah 5 orang.

\section{HASIL DAN PEMBAHASAN}

Responden wanita sebagian besar adalah ibu rumah tangga sedangkan responden pria sebagian besar berwirausaha. Data karakteristik responden disajikan pada Tabel 5.1. Responden menderita HIV/AIDS antara 7 bulan sampai dengan 8 tahun, dan telah didampingi oleh komunitas sosial perduli HIV/AIDS "Jalak Bali" di Kabupaten Jembrana.

Tabel 1. Karakteristik Responden

\begin{tabular}{|c|c|c|c|c|c|}
\hline \multirow[t]{2}{*}{ Karakteristik responden } & \multicolumn{2}{|c|}{ Wanita } & \multicolumn{2}{|c|}{ Pria } & \multirow[t]{2}{*}{$\mathrm{p}$} \\
\hline & $\mathrm{N}$ & $\%$ & $\mathrm{n}$ & $\%$ & \\
\hline Usia & & & & & ( \\
\hline $18-25$ & 3 & 12,5 & 0 & 0 & \\
\hline $26-30$ & 4 & 16,67 & 4 & 16 & \\
\hline $31-35$ & 8 & 33,33 & 8 & 32 & \\
\hline $36-40$ & 3 & 12,5 & 6 & 24 & \\
\hline $41-45$ & 3 & 12,5 & 2 & 8 & \\
\hline$>45$ & 3 & 12,5 & 5 & 20 & \\
\hline \multicolumn{6}{|l|}{$\overline{\text { Pendidikan }}$} \\
\hline SD & 8 & 33,33 & 5 & 20 & 0,565 \\
\hline SLTP & 9 & 37,5 & 10 & 40 & \\
\hline SLTA & 7 & 29,17 & 10 & 40 & \\
\hline
\end{tabular}




\begin{tabular}{llllll}
\hline Karakteristik responden & \multicolumn{2}{c}{ Wanita } & Pria & & p \\
& $\mathrm{N}$ & $\%$ & $\mathrm{n}$ & $\%$ & $0,000^{*}$ \\
\hline \hline Pekerjaan & & & & & \\
$\begin{array}{l}\text { Ibu Rumah Tangga (IRT) } \\
\text { tidak bekerja }\end{array}$ & 18 & 75 & 1 & 4 & \\
Pegawai Swasta & 3 & 12,5 & 6 & 24 & \\
Wirausaha & 1 & 4,17 & 9 & 36 & \\
Volentri & 1 & 4,17 & 0 & 0 & \\
Petani & 0 & 0 & 4 & 16 & \\
Buruh & 1 & 4,17 & 1 & 4 & \\
Sopir & 0 & 0 & 2 & 8 & \\
Lain-lain & 0 & 0 & 2 & 8 & \\
* & & & & &
\end{tabular}

\section{Sumber Infeksi HIV/AIDS}

HIV/AIDS dapat menular melalui hubungan seks bebas (Oppong, 2013), tranfusi darah yang tercemar HIV/AIDS, penggunaan jarum suntik yang telah digunakan oleh orang yang positif mengidap HIV/AIDS, dan ibu hamil yang mengidap HIV/AIDS terhadap janin yang dikandungnya (Kementrian Kesehatan Republik Indonesia, 2014).

Hasil penelitian ini menunjukkan bahwa sumber infeksi HIV/AIDS di Kabupaten Jembrana yang dilakukan oleh responden pria berasal dari hubungan heteroseksual yaitu sebanyak $80 \%$. Data disajikan pada Tabel 5.2. Sedangkan sebanyak $87,5 \%$ responden wanita mengidap HIV/AIDS disebabkan oleh pasangan hidupnya. Hal ini menunjukkan bahwa opini masyarakat Kabupaten Jembrana yang menyatakan bahwa wanita yang mengidap HIV/AIDS disebabkan karena melakukan hubungan heteroseksual, tidaklah tepat. Ada beberapa pasangan suami istri pada penelitian ini, dan berdasarkan data yang diperoleh terlihat bahwa suami (responden pria) yang melakukan hubungan heteroseksual akan menularkan HIV/AIDS kepada istri (responden wanita).

Hasil penelitian ini juga menunjukkan bahwa hubungan homoseksual juga menjadi sumber infeksi HIV/AIDS. Sebanyak $8 \%$ responden pria terinfeksi HIV/AIDS yang diakibatkan oleh hubungan seksual. Chingwaru and Jerneja (2015) melaporkan bahwa peningkatan epidemik HIV/AIDS di Zimbabwe dari tahun 1985 sampai 2015 yang terbesar disebabkan oleh perilaku seksual yang beresiko.

Analisis statistik menggunakan crosstab dengan chi-square test, hubungan jenis kelamin dengan sumber infeksi HIV/AIDS pada responden memberikan nilai $\mathrm{p}$ sebesar 0,000. Berdasarkan analisis statistik tersebut dapat diketahui bahwa ada perbedaan yang signifikan antara jenis kelamin terhadap sumber infeksi HIV/AIDS pada responden.

Tabel 2. Sumber Infeksi HIV/AIDS

\begin{tabular}{llllll}
\hline \multirow{2}{*}{ Sumber infeksi HIV } & \multicolumn{2}{l}{ wanita } & Pria & \multirow{2}{*}{ P } \\
& $\mathrm{N}$ & $\%$ & $\mathrm{~N}$ & $\%$ & \\
\hline \hline Heteroseksual & 3 & 12,5 & 20 & 80 & \multirow{2}{*}{$0,000^{*}$} \\
Homoseksual & 0 & 0 & 2 & 8 & \\
Pasangan & 21 & 87,5 & 3 & 12 & \\
\hline
\end{tabular}

$* \mathrm{p}<0,05$

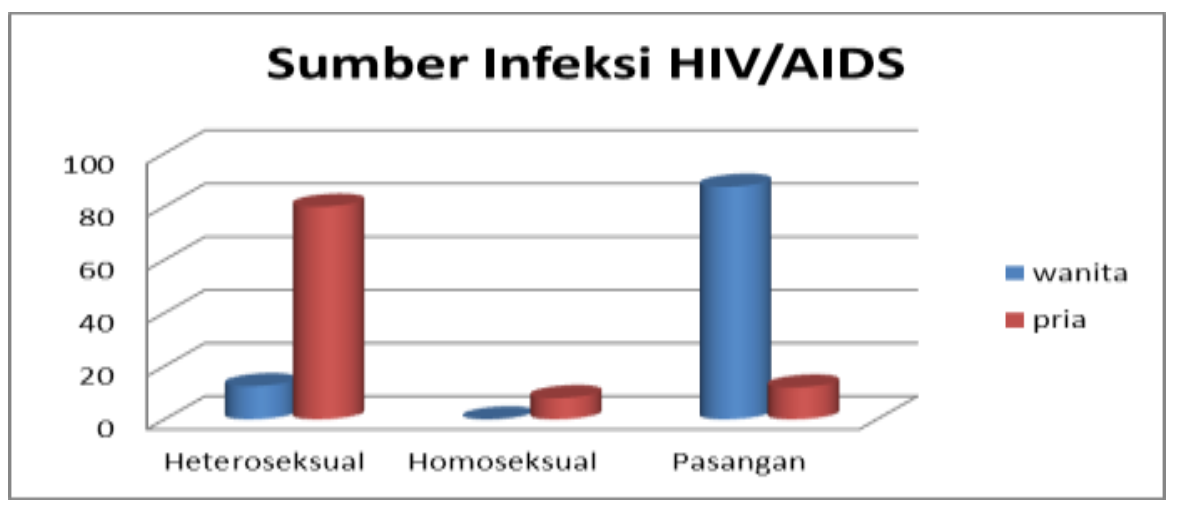

Gambar 1. Sumber Infeksi HIV/AIDS 


\section{Pekerjaan Pasangan}

Penyebaran HIV/AIDS dapat disebabkan oleh pasangan. Untuk mengetahui darimana HIV/AIDS itu ditularkan maka peneliti melakukan identifikasi pekerjaan pasangan.

Hasil penelitian ini menunjukkan bahwa sebesar 33,3\% pasangan responden wanita bekerja wirausaha, sedangkan sebesar $40 \%$ pasangan responden pria adalah ibu rumah tangga. Melalui penelusuran pekerjaan pasangan maka dapat mendukung data sumber infeksi HIV/AIDS di Kabupaten Jembrana. Data lebih lengkap disajikan pada Tabel 5.3 dan Gambar 5.2.
Analisis statistik menggunakan crosstab dengan chi-square test, hubungan jenis kelamin dengan sumber infeksi HIV/AIDS pada responden memberikan nilai $\mathrm{p}$ sebesar 0,149 dan dengan korelasi Spearman memberikan nilai $\mathrm{p}$ sebesar 0,195 . Berdasarkan analisis statistik tersebut dapat diketahui bahwa tidak ada perbedaan yang signifikan antara sumber infeksi HIV/AIDS terhadap pekerjaan pasangan pada responden. Hal ini dapat disebabkan karena penyakit HIV/AIDS merupakan penyakit perilaku seksual, sehingga apapun jenis pekerjaannya jika memiliki perilaku seksual yang buruk maka dapat terkena penyakit HIV/AIDS.

Tabel 3. Pekerjaan Pasangan

\begin{tabular}{llllll}
\hline \multirow{2}{*}{ Pekerjaan Pasangan } & Wanita & Pria & p \\
& $\mathrm{n}$ & $\%$ & $\mathrm{n}$ & $\%$ & \\
\hline \hline IRT/tidak bekerja & 2 & 8,33 & 10 & 40 & \\
Pegawai Swasta & 7 & 29,17 & 5 & 20 & \\
Wirausaha & 8 & 33,33 & 3 & 12 & \multirow{2}{*}{0,149} \\
Sopir & 2 & 8,33 & 0 & 0 & \\
Buruh & 2 & 8,33 & 0 & 0 & \\
Petani & 1 & 4,17 & 0 & 0 & \\
Tidak menjawab & 5 & 20,83 & 6 & 24 &
\end{tabular}

$* \mathrm{p}<0,05$

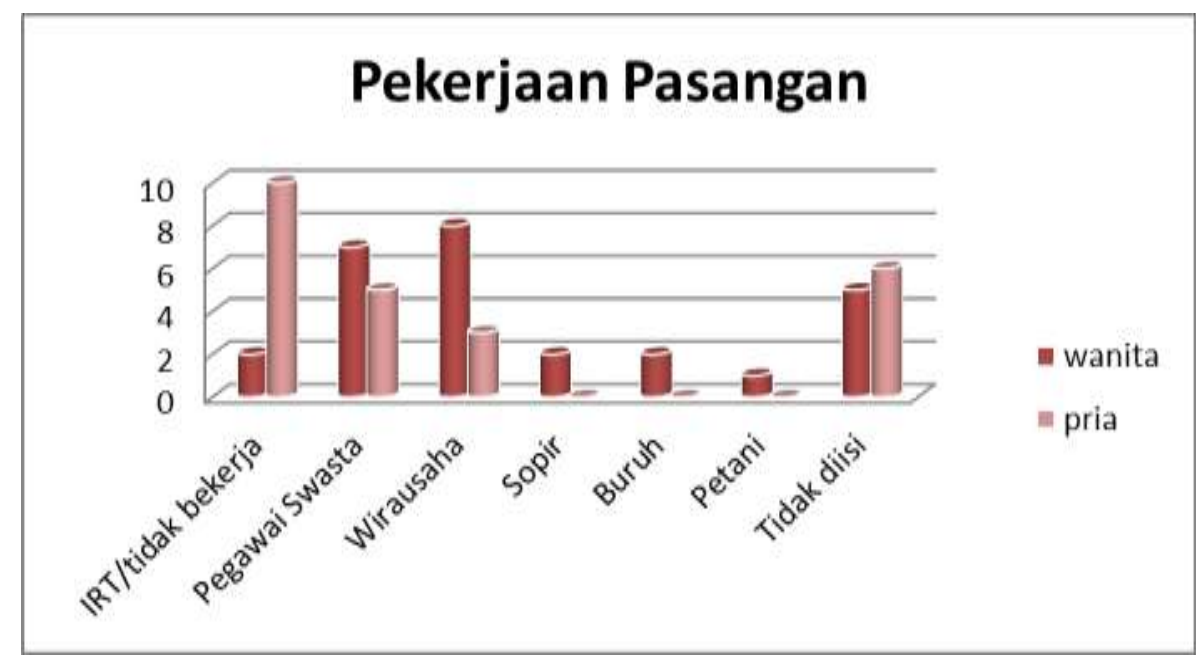

Gambar 2. Pekerjaan Pasangan

\section{Status HIV/AIDS}

HIV/AIDS tidak mudah diketahui kapan awal mulai terjangkitnya. Tanda dan gejala klinis penderita AIDS menyerupai gejala penyakit pada umumnya, sehingga sulit membedakan seseorang terkena AIDS atau tidak. Penderita AIDS umumnya mengalami penurunan berat badan sebesar $10 \%$. Gejala lain yang dialami penderita AIDS yaitu mengalami diare kronik kira-kira lebih dari 30 hari, badan terasa lesu dan demam selama 30 hari bahkan bias lebih (Centers for Disease Control, 1987; McMahon, 1997; Chingwaru and Jerneja, 2015), bercak-bercak putih di lidah dan di dalam mulut, pembengkakan leher dan lipatan paha, radang paru-paru dan kanker kulit (Siregar, 2004). 
Hasil penelitian ini menunjukkan sebanyak $33,3 \%$ dan $32 \%$ masing-masing responden wanita dan pria telah terinfeksi HIV/AIDS selama 4 tahun.
Data lebih lengkap disajikan pada Tabel 4 dan Gambar.3

Tabel 4. Status HIV/AIDS

\begin{tabular}{lllll}
\hline $\begin{array}{l}\text { Status } \\
\text { AIDS } \\
\text { (bulan) }\end{array}$ & HIV/ & \multicolumn{2}{l}{ Wanita } & pria \\
\hline 6 & $\mathrm{n}$ & $\%$ & $\mathrm{~N}$ & $\%$ \\
7 & 1 & 4,2 & 0 & 0 \\
12 & 1 & 4,2 & 0 & 0 \\
24 & 2 & 8,3 & 4 & 16 \\
30 & 4 & 16,7 & 3 & 12 \\
36 & 0 & 0 & 1 & 4 \\
48 & 2 & 8,3 & 3 & 12 \\
60 & 8 & 33,3 & 8 & 32 \\
72 & 4 & 16,7 & 4 & 16 \\
96 & 1 & 4,2 & 1 & 4 \\
\hline
\end{tabular}

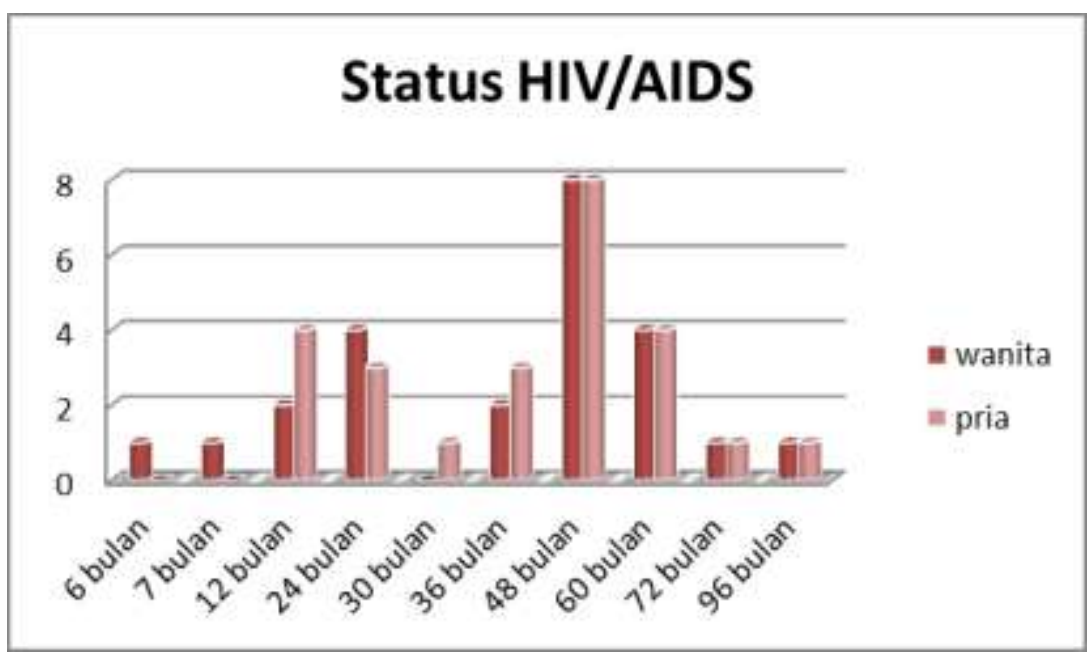

Gambar 3. Status HIV/AIDS

\section{Mengetahui Jika Mengidap HIV/AIDS}

Pengidap HIV/AIDS umumnya tidak mengetahui bahwa dirinya telah terinfeksi HIV. Hal ini disebabkan tanda dan gejala klinis penderita AIDS menyerupai gejala penyakit pada umumnya (Centers for Disease Control, 1987; McMahon, 1997) seperti penyakit flu dan batuk. Sehingga sulit dilakukan deteksi oleh diri sendiri.

Hasil penelitian ini menunjukkan bahwa sebanyak $66,7 \%$ dan $64 \%$ masing-masing responden wanita dan pria mengetahui bahwa dirinya mengidap HIV/AIDS berdasarkan informasi dari petugas kesehatan. Data lebih lengkap disajikan pada Tabel 5.5 dan Gambar 5.4. Wawancara yang kami lakukan dengan responden diketahui bahwa pada awalnya responden mengalami sakit tuberkulosis (TB), kemudian saat memeriksakan diri ke dokter disarankan oleh petugas kesehatan untuk melakukan tes darah guna memastikan bahwa dirinya hanya TB atau sudah terinfeksi HIV. Streck (2015) melaporkan bahwa laju kematian HIV/AIDS disebabkan oleh tingginya prevalensi HIV/AIDS dengan TB.

Tabel 5. Mengetahui Jika Mengidap HIV/AIDS

\begin{tabular}{lcccc}
\hline $\begin{array}{l}\text { Mengetahui jika } \\
\text { HIV/AIDS }\end{array}$ & mengidap & \multicolumn{3}{c}{ Pria } \\
& wanita & \multicolumn{3}{c}{} \\
\hline \hline Petugas kesehatan & $\mathrm{n}$ & $\%$ & $\mathrm{n}$ & $\%$ \\
Aktivis/LSM & 16 & 66,7 & 16 & 64 \\
Diri sendiri & 8 & 33,3 & 7 & 28 \\
\hline
\end{tabular}




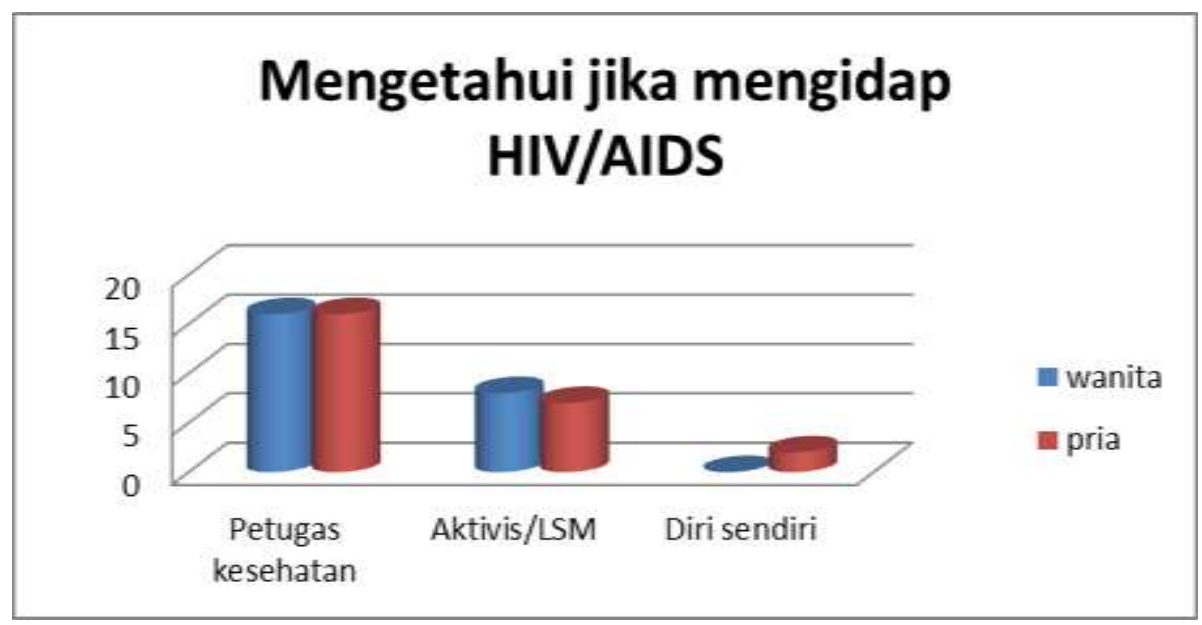

Gambar 4. Mengetahui status HIV/AIDS

\section{Penggunaan antiretroviral (ARV)}

Antiretroviral (ARV) merupakan salah cara untuk mengobati infeksi yang disebabkan oleh HIV (Streck, 2015). ARV mengandung protease inhibitor sehingga dapat mengobati virus HIV sampai virus HIV tidak terdeteksi dalam darah penderita HIV/AIDS (Roberts, 2002).

Hasil wawancara dengan responden diketahui bahwa $91,7 \%$ dan $100 \%$ masing-masing responden wanita dan pria telah melakukan pengobatan dengan menggunakan ARV. Data disajikan pada Tabel 5.6 dan Gambar 5.5. Dalam sehari rata-rata mereka mengkonsumsi 4 butir ARV. Sebanyak $2 \%$ responden wanita belum melakukan pengobatan dengan ARV. Hal ini disebabkan nilai CD4 yang masih tinggi sehingga belum memerlukan pengobatan.

Penderita HIV/AIDS harus mengkonsumsi obat antiretroviral secara teratur. Ketidakteraturan mengkonsumsi obat antiretroviral dapat menyebabkan kegagalan dalam pengobatan dikarenakan virus HIV menjadi resistan (Roberts, 2002). Chingwaru and Jerneja (2015) melaporkan tingkat kematian wanita penderita HIV/AIDS di Zimbabwe meningkat saat tidak melakukan pengobatan ARV. Berdasarkan penelitian yang dilakukan oleh Mutasa-Apollo et al (2014), ARV dapat meningkatkan berat badan dan jumlah sel CD4 penderita HIV/AIDS dalam 6 bulan.

Tabel 6. Penggunaan ARV

\begin{tabular}{lllll}
\hline \multirow{2}{*}{ ARV } & \multicolumn{3}{l}{ Wanita } & Pria \\
& $\mathrm{N}$ & $\%$ & $\mathrm{n}$ & $\%$ \\
\hline \hline Sudah & 22 & 91,7 & 25 & 100 \\
Belum & 2 & 8,3 & 0 & 0 \\
\hline
\end{tabular}

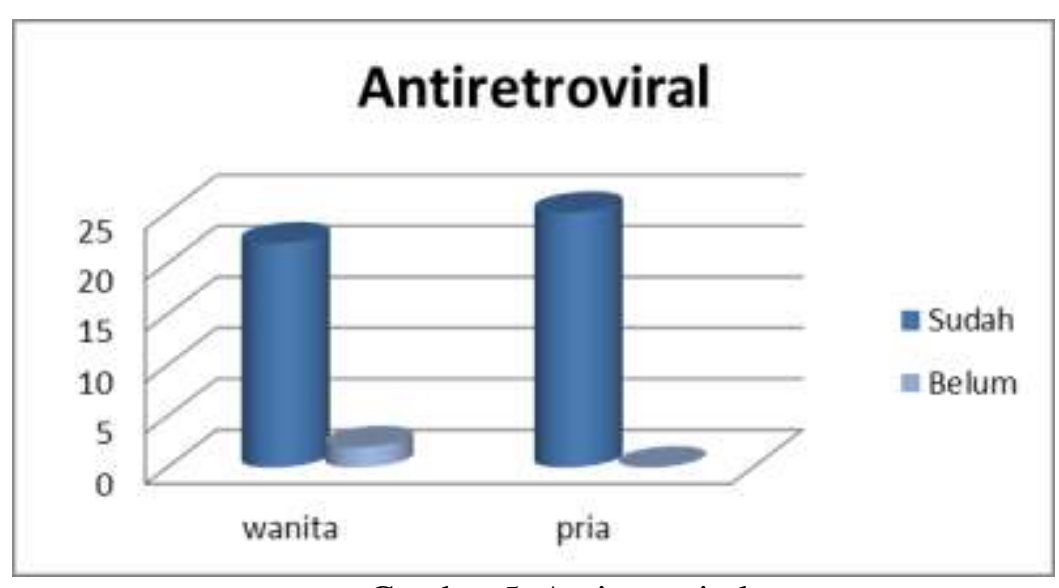

Gambar 5. Antiretroviral 


\section{Perasaan}

Seseorang yang pertama kali didiagnosa mengidap HIV/AIDS memiliki perasaan yang berbeda-beda, ada yang sedih, kecewa, marah tetapi juga yang pasrah menerima karena merasa inilah takdir hidupnya. Hasil wawancara dengan responden menunjukkan bahwa $66,7 \%$ dan $60 \%$ masing-masing responden wanita dan pria merasa sedih saat pertama kali mengetahui bahwa dirinya mengidap HIV/AIDS. Hanya $12 \%$ baik itu responden wanita maupun pria yang menerima dengan pasrah saat mengetahui dirinya mengidap HIV/AIDS. Data disajikan pada Tabel 7.

HIV/AIDS umumnya dikaitkan dengan penyakit yang diakibatkan oleh perilaku
(Chingwaru and Jerneja, 2015). Sehingga keluarga serta masyarakat akan berpendapat bahwa penderita HIV/AIDS adalah seorang yang berperilaku buruk. Berdasarkan hasil wawancara dengan responden dinyatakan bahwa pada awalnya saat menginformasikan bahwa dirinya mengidap HIV/AIDS, keluarga merasa sedih dan mempersalahkan. Sekitar 66,7\% dan 64\% masingmasing keluarga responden wanita dan pria, pada akhirnnya dapat menerima bahwa responden mengidap HIV/AIDS. Dan masyarakat yang awalnya menjauhi responden akhirnya juga dapat menerima. Berdasarkan Tabel 7 diketahui sekitar $50 \%$ dan $64 \%$ masing-masing responden wanita dan pria dapat diterima oleh masyarakat.

Tabel 7. Perasaan Responden, Tanggapan Keluarga dan Masyarakat saat mengetahui mengidap HIV/AIDS

\begin{tabular}{|c|c|c|c|c|}
\hline \multirow{2}{*}{$\begin{array}{llr}\begin{array}{l}\text { Perasaan } \\
\text { mengetahui }\end{array} & \text { saat } & \text { pertama } \\
\text { HIV/AIDS } & & \\
\end{array}$} & \multicolumn{2}{|c|}{ wanita } & \multicolumn{2}{|c|}{ Pria } \\
\hline & $\mathrm{N}$ & $\%$ & $\mathrm{n}$ & $\%$ \\
\hline Sedih & 16 & 66,7 & 15 & 60 \\
\hline Kecewa & 3 & 12,5 & 5 & 20 \\
\hline Marah & 2 & 8,3 & 0 & 0 \\
\hline Menerima & 1 & 12 & 3 & 12 \\
\hline Tidak menjawab & 2 & 8 & 2 & 8 \\
\hline $\begin{array}{lr}\text { Tanggapan } & \text { keluarga } \\
\text { mengetahui } & \text { mengidap }\end{array}$ & \multicolumn{2}{|c|}{ wanita } & \multicolumn{2}{|c|}{ Pria } \\
\hline HIV/AIDS & $\mathrm{N}$ & $\%$ & $\mathrm{n}$ & $\%$ \\
\hline "Menerima dan mempersalahkan & 2 & 8,3 & 3 & 12 \\
\hline Menerima & 16 & 66,7 & 16 & 64 \\
\hline Tidak tahu & 4 & 16,7 & 3 & 12 \\
\hline Sedih & 0 & 0 & 1 & 4 \\
\hline Kecewa & 0 & 0 & 1 & 4 \\
\hline Tidak menjawab & 2 & 8,3 & 1 & 4 \\
\hline $\begin{array}{lr}\text { Tanggapan } & \text { masyarakat saat } \\
\text { mengetahui } & \text { mengidap }\end{array}$ & \multicolumn{2}{|c|}{ wanita } & \multicolumn{2}{|c|}{ Pria } \\
\hline HIV/AIDS & $\mathrm{N}$ & $\%$ & $\mathrm{n}$ & $\%$ \\
\hline Menerima & 12 & 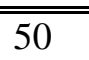 & 16 & 64 \\
\hline Tidak tahu & 8 & 33,3 & 5 & 20 \\
\hline Acuh & 0 & 0 & 1 & 4 \\
\hline Mempersalahkan & 1 & 4,2 & 1 & 4 \\
\hline Takut mendekat & 0 & 0 & 1 & 4 \\
\hline Tidak menjawab & 3 & 12,5 & 1 & 4 \\
\hline
\end{tabular}

\section{SIMPULAN}

Kesimpulan pada penelitian ini adalah epidemologi HIV/AIDS di Kabupaten Jembrana disebabkan oleh perilaku hubungan :

Heteroseksual yaitu sebesar $12,5 \%$ dan $80 \%$ masing-masing responden wanita dan pria. Homoseksual sebesar $8 \%$ responden pria. Tertular oleh pasangan yaitu sebesar $87,5 \%$ dan $12 \%$ masing-masing responden wanita dan pria.

\section{DAFTAR PUSTAKA}

Aydin, O. A., Hayat, K.K., Ridvan, K., Meryem T., and Ozcan N. 2013. Prevalence and risk factors of osteopenia/osteoporosis in Turkish HIV/AIDS patients. Brazj J Infect dis, 17 (6) : 707-711.

Borderi, M., Davide G., Fabio V., Elida D. C., Laura C., Carlo B., Livia T., and Maria C. R. 2009. Review : Metabolic bone disease in HIV infection. AIDS, 23:1297-1310.

Bradley-Springer, L. 2015. The National HIV/AIDS Strategy : Updated for the Future. Journal of the Association of Nurses in AIDS Care, 26 (6) : 689-692.

Centers for Disease Control. 1987. Revision of the CDC surveillance case definition for 
acquired immunodeficiency syndrome. Journal of the American Medical Association, 258s : 1143-1153.

Cingwaru, W and Jerneja. V. 2015. Review article: Thirty years on with an HIV epidemic in Zimbabwe (1985-2015). HIV and AIDS Review.

Ditjen PP dan PL Kemenkes RI. 2014. Statistik Kasus HIV/AIDS di Indonesia (available online 27 Agustus 2015).

Greeson, J.M., Barry E.H., Maria M.L., Neil S., Frank J.P., Nancy G.K. 2008. Psychological distress, killer lymphocytes and disease severity in HIV/AIDS. Brain, Behavior and Immunity 2 : 901-911.

Hanizar, E., Adzkiyak. And Kayan S. 2015. Prevention of Transmission of HIV/AIDS through Local Social Organization On Jember Fishermen Community. Procedia Environmental Science 23 : 136-141.

Harvey N \& Cooper C. 2004. Pencegahan Penyakit Osteoporosis dan Fraktur Panggul, dalam Buku Gizi Kesehatan Masyarakat (Public Health Nutrition). EGC, Jakarta.

Hermanus, A.M.Z., Ahmad H.A., Ali G.M., Jozh M. 2010. Perilaku dan Resiko Penyakit HIVAIDS di Masyarakat Papua Studi Pengembangan Model Lokal Kebijakan HIV-AIDS. Jurnal Manajemen Pelayanan Kesehatan.

Kartsogiannis V, Ng KW. 2004. Cell lines and primary cell cultures inthe study of bone cell biology. Mol Cell Endocrinol, 228:79-102.

Kementerian Kesehatan Republik Indonesia. 2014. Situasi dan Analisis HIV AIDS. Infodatin Pusat Data dan Informasi Kementerian Kesehatan RI (available online 27 Agustus 2015).

Lin, LP., Shang-Wei H., Chung-Hui Y., Wei-Ju L., Pei-Jung H., Jian-Ling W., Cordia M.C., and Jin-Ding L. 2015. Risk for osteopenia and osteoporosis in institution-dwelling individuals with intellectual and/or developmental disabilities. Research in developmental disabilities $36: 108-113$.

McMahon, K.C. 1997. Malnutrition Associated With HIV/AIDS. Part One : Definition and Scope, Epidemiology and Pathophysiology. Journal of the association of nurses in AIDS care 8 (3) : 24-32.

Mutasa-Apollo, T., R.W. Shiraishi., and K.C. Takarinda. 2014. Patient retention, clinical outcomes and attrition-associated factors oh HIV-infected patients enrolled in Zimbabwe's National Antiretroviral Therapy Programme 2007-2010. Plos One 9 (1).

National AIDS Commision Republic Indonesia. 2009. Republic of Indonesia Country Report on the Follow Up to the Declaration of Commitment on HIV/AIDS (UNGASS).

Noor Zairin. 2014. Buku Ajar Osteoporosis. Jakarta : Salemba Medika.

Olson RE, Broquist HP, Darby WJ, Kolbye AC, Stalvey RM. 1988. Pengetahuan Gizi Mutakhir Mineral (Buku 2). Gramedia, Jakarta

Oppong, K.A. 2013. HIV/AIDS knowledge and uptake of HIV counselling and testing among undergraduate private university students in Accra, Ghana. Reproductive Health, 10:17.

Peacock, M. 2010. Calcium Metabolism in Health and Disease. Clin J Am Soc Nephrol 5 : S23S30.

Pinzone, M.R., M. Di Rosa., M. Malaguarnera., G Madeddu., E. Foca., G Ceccarelli., G D'Ettorre., V Vullo., R Fisichella., B Cacopardo., and G Nunnari. 2013. Vitamin $D$ deficiency in HIV infection: an underestimated and undertreated epidemic. Medical and Pharmacological Sciences 17: 1218-1232.

Polit, D.F., Bect C.T and Hungler B.P. 2001. Essentials of nursing research : methods, appraisal, and utilization. Fifth edition. Philadelphia : Lippincott.

Riskesdas. 2013. Menkes RI No. 75 Angka Kecukupan Gizi.

Rude, RK and Helen EG. 2004. Review : Magnesium deficiency and osteoporosis: animal and human observations. Journal of Nutritional Biochemistry $15: 710-716$.

Roberts, K.J. 2002. Physician-Patient Relationships, Patient Satisfaction, and Antiretroviral Medication Adherence Among HIV-Infected Adults Attending a Public Health Clinic. AIDS Patient Care and STDs, $16: 1$.

Sastro Asmoro dan Sofyan Ismael. 2008. Dasardasar metodelogi penelitian klinis. Jakarta : CV. Sagung Seto.

Siregar, F. A. 2004. Pengenalan dan Pencegahan AIDS. Digitized by USU digital library.

Spear, BA. 2004. Nutrition in Adolescence. Dalam Mahan K \& Stump SE (Eds.), Food, Nutrition \& Diet Therapy 11th ed. Saunders, Pennsylvania.

Streck, O. 2015. Natural resources and the spread of HIV/AIDS: Curse or blessing? Social Science and Medicine 1-8.

Supariasa, I Dewa Nyoman; Bachyar Bakri; Ibnu Fajar. 2001. Penilaian Status Gizi. Jakarta : Kedokteran ECG.

Teran, C.C., Dorian G.U., Cristina G.B., Belen A.F., Oriana R.R., Francisco B.M., Marta O.R and Julia d.A.V. 2015. Knowledge, 
attitudes and practices on HIV/AIDS and prevalence of HIV in the general population of Sucre, Bolivia. Braz J Infect Dis. 19 (4) : 369-375.

Tirthayasa, M. 2015. KJB lakukan pendampingan pengidap HIV/AIDS di Jembrana. http://www.dewatanews.com/2015/07/kjblakukan-pendampingan-pengidap-hiv.html (available online 2 September 2015).

Yin, M.T., Qiuhu S., Donald R.H., Kathryn A., Anjali S., Mary Y., Alexandra L., Mardge H.
C., Elizabeth S., Elizabeth T. G., and Phyllis C. T. 2010. Fracture incidence in HIVinfected women: results from the Women's Interagency HIV Study. AIDS, 24 (17) : 2679-2686.

Wang L, Nancollas GH, Henneman ZJ. 2006. Nanosized particles in bone and dissolution insensitivity of bone mineral. Biointerphases 1: 106-11. 